\title{
Intracranial Meningiomas among Intracranial Tumors in the Neurosurgical Unit of Sylvanus Olympio Teaching Hospital
}

\author{
${ }^{1}$ Service de Neurochirurgie, CHU Sylvanus Olympio, Lomé, Togo \\ ${ }^{2}$ Service d'Oncologie Médicale, CHU Sylvanus Olympio, Lomé, Togo \\ ${ }^{3}$ Service de Neurochirurgie, Hôpital militaire de Yaoundé, Yaoundé, Cameroon \\ ${ }^{4}$ Service d'Anesthésie-Réanimation, CHU Sylvanus Olympio, Lomé, Togo \\ ${ }^{5}$ Polyclinique Internationale Saint Joseph, Lomé, Togo \\ Email: *achilledoleagbenou@gmail.com
}

Komlan A. Doléagbénou ${ }^{*}$, Essossinam Kpélao', Ablavi O. Adani-Ifè2, Katanga A. Békéti1, Ben O. Djoubairou ${ }^{3}$, Kodjo H. M. Ahanogbé1, Pilakimwé Egbohou ${ }^{4}$, Eklu Vossah ${ }^{5}$, Komi Egu ${ }^{5}$

How to cite this paper: Doléagbénou, K.A., Kpélao, E., Adani-Ifè, A.O., Békéti, K.A., Djoubairou, B.O., Ahanogbé, K.H.M., Egbohou, P., Vossah, E. and Egu, K. (2020) Intracranial Meningiomas among Intracranial Tumors in the Neurosurgical Unit of Sylvanus Olympio Teaching Hospital. Open Journal of Modern Neurosurgery, 10, 345-352.

https://doi.org/10.4236/ojmn.2020.103037

Received: April 22, 2020

Accepted: June 27, 2020

Published: June 30, 2020

Copyright $\odot 2020$ by author(s) and Scientific Research Publishing Inc. This work is licensed under the Creative Commons Attribution International License (CC BY 4.0).

http://creativecommons.org/licenses/by/4.0/ (c) (i) Open Access

\begin{abstract}
Objective: To describe the pattern of intracranial tumors in Sylvanus Olympio teaching hospital of Lomé (Togo). Method: We conducted a retrospective and descriptive study between November 2017 and December 2019. Data were obtained from the clinical records of patients with intracranial tumors treated in our neurosurgery unit, and histology obtained. Patients without a definitive histological diagnosis were excluded. Results: 53 patients were operated and had a histological diagnosis in the period of the study. The mean age at diagnosis was $32 \pm 27.1$ years. The majority of tumors were seen in adults at $88.7 \%$ with age range between $23-75$ years and a mean age of $40 \pm$ 10.5 years. Meningioma was the commonest intracranial tumor in adults (47.2\%) and more seen in females. The histological type of meningioma is meningotheliomatous in our study. In children, principal tumors were medulloblastoma and ependymoma (11.3\%). Conclusion: Meningioma is the most common intracranial tumor in adults, while embryonal tumors (medulloblastoma and ependymoma) are the most frequent in children in our environment.
\end{abstract}

\section{Keywords}

Meningioma, Intracranial Tumor, Togo

\section{Introduction}

Intracranial tumors arise from the brain or its surrounding tissues. They are a 
major cause of morbidity and mortality worldwide [1]. Advances in neuroimaging have improved the diagnosis of intracranial neoplasms. Epidemiologies of intracranial tumors have been reported in Africa [2] [3] [4] [5]. The prevalence of meningiomas among intracranial neoplasms differs from authors [6] [7]. There is limited data on the patterns of intracranial tumors in Togo. The objective of this study is to determine the prevalence of meningiomas among intracranial neoplasms in a single neurosurgical unit of Sylvanus Olympio Teaching Hospital.

\section{Patients and Method}

After the approval of the local ethics committee in Sylvanus Olympio teaching hospital, we conducted a retrospective and descriptive study between November 2017 and December 2019, in the neurosurgical unit. Data were obtained from the hospital records of patients undergoing craniotomy for tumor resection. The intracranial tumors were diagnosed by Computed Tomography scan and Magnetic Resonance Imaging. The following data were analyzed: patient demographics (age and gender), presenting symptoms, signs, and histopathology of the tumor. The cases that were excluded from surgeries were patients with Karnofsky Performance Scale below 70, and patients presenting with brain metastases who had an uncontrolled primary disease or multiple brain masses. For each case, we considered the risk to the patients' lives or their morbidity, and keeping in mind the limited intraoperative equipment, to plan the resection extension. All pituitary adenoma were operated in another center with better equipment than ours. In our conditions, intraoperative preparation included positioning without the use of Mayfield headrest (Figure 1). We didn't use image guidance in any of our patients. Postoperative care for patients was provided by a basically equipped general ICU with no dedicated neurocritical care nursing staff or equipment. No intracranial pression, or electroencephalography monitoring was available in the ICU.

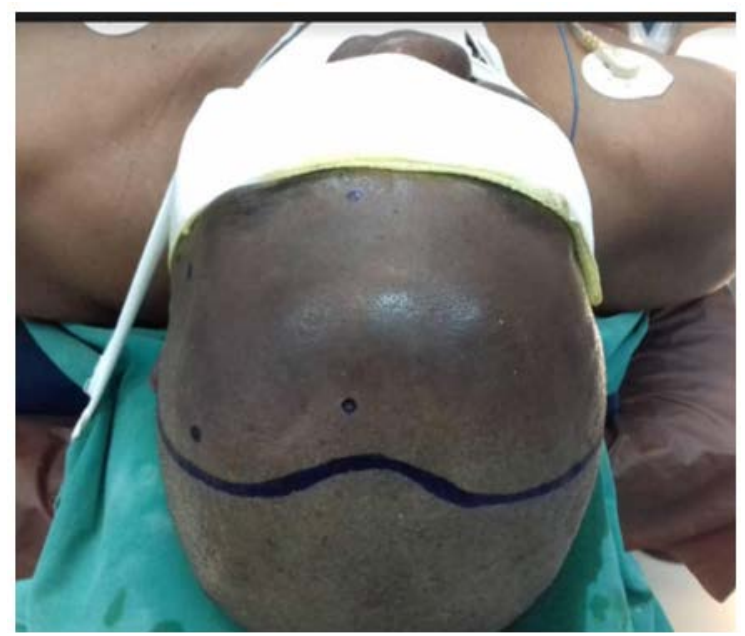

Figure 1. Patient positioning for craniotomy. 


\section{Results}

Eighty-two patients with intracranial tumors have been seen during the period. A total of 53 patients were operated and had a histological diagnosis in the period of the study.

There were more female patients with intracranial tumors, sex ratio $=0.6$ (Table 1).

The mean age at diagnosis was $32 \pm 27.1$ years. The majority of tumors were seen in adults at $88.7 \%$ with age range between $23-75$ years and a mean age of $40 \pm 10.5$ years. In children, principal tumors were medulloblastoma and ependymoma (11.3\%).

Meningioma was the commonest intracranial tumor in adults (47.2\%). According to the WHO classification of nervous system tumors, the meningotheliomatous type was the most frequent type (Table 2). Meningioma had a female preponderance (Table 3 ) with a statistically significant $(\mathrm{p}=0.025)$. The quality of resection was Simpson grade 1 in $40 \%$ (Figure 2), grade 2 in 50\%, and grade 3 in $10 \%$.

Pituitary adenoma and metastatic tumors account for $18.8 \%$ and $13.2 \%$ respectively (Table 1 ).

The commonest symptoms and signs in patients with intracranial tumors are resumed in Table 4. The percentages were calculated based on 48 patients with detailed symptomatology.

The majority of tumors were located in supratentorial (Table 5). Figure 3 shows the distribution of meningioma based on location.

In the outcome, the surgical site infection was $3.5 \%$, and the mortality of our series was $13.2 \%$.

Table 1. Tumour histopathology and gender distribution.

\begin{tabular}{cccc}
\hline Tumour & Number & Male & Female \\
\hline Meningioma & $25(47.2 \%)$ & $7(28 \%)$ & $18(72 \%)$ \\
Glioma & $5(9.4 \%)$ & $2(4 \%)$ & $3(60 \%)$ \\
Pituitary adenoma & $10(18.8 \%)$ & $6(60 \%)$ & $4(40 \%)$ \\
Medulloblastoma & $3(5.7 \%)$ & $2(66.67 \%)$ & $1(33.33 \%)$ \\
Ependymoma & $3(5.7 \%)$ & $1(33.33 \%)$ & $2(66.67 \%)$ \\
Metastatic tumour & $7(13.2 \%)$ & $2(28.57 \%)$ & $5(71.43 \%)$ \\
Total & $53(100 \%)$ & $20(37.8 \%)$ & $33(62.2 \%)$ \\
\hline
\end{tabular}

Table 2. Histological types of meningioma.

\begin{tabular}{cc}
\hline Meningioma & Number (\%) \\
\hline Meningotheliomatous & $14(56 \%)$ \\
Atipycal & $2(8 \%)$ \\
Microcystic & $8(32 \%)$ \\
Anaplastic & $1(4 \%)$
\end{tabular}


Table 3. Meningiomas mean age distribution and gender.

\begin{tabular}{ccccc}
\hline & Total & Male & Female & p-value \\
\hline Number of patients & 25 & 7 & 18 & 0.025 \\
Age range in years & & $32-73$ & $26-75$ & \\
Overall mean age in years & & 33 & 28 & 0.45 \\
\hline
\end{tabular}

Table 4. Symptoms and signs.

\begin{tabular}{ccc}
\hline Symptoms/signs & Frequency & $\%$ \\
\hline Headache & 38 & $79.17 \%$ \\
Visual disturbance & 22 & $45.88 \%$ \\
Hemiparesis & 28 & $58.33 \%$ \\
Seizure & 12 & $25 \%$ \\
Gait abnormality & 6 & $12.5 \%$ \\
Vomiting & 18 & $37.5 \%$ \\
Cranial nerve palsy & 4 & $8.33 \%$ \\
Altered mentation & 9 & $18.75 \%$ \\
Speech abnormality & 3 & $6.75 \%$ \\
\hline
\end{tabular}

Table 5. Tumour location.

\begin{tabular}{ccc}
\hline Tumor type & Supratentorial & Infratentorial \\
\hline Meningioma & $25(100 \%)$ & 0 \\
Glioma & $2(40 \%)$ & $3(60 \%)$ \\
Pituitary adenoma & $10(100 \%)$ & 0 \\
Medulloblastoma & $3(100 \%)$ & 0 \\
Metastatic tumor & $5(71.42 \%)$ & $2(28.58 \%)$ \\
\hline
\end{tabular}

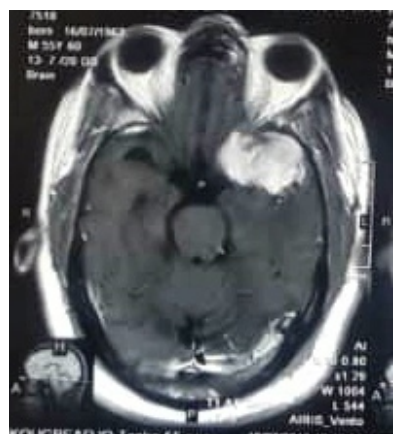

(a)

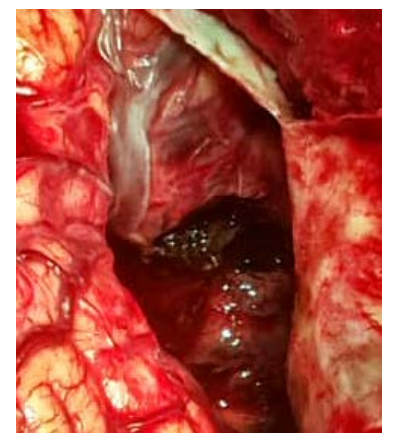

(b)

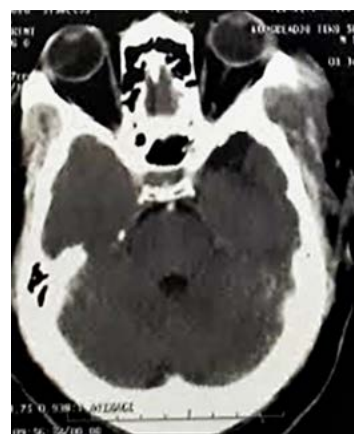

(c)

Figure 2. Spheno-orbital meningioma. (a) Pre operative CT scan; (b) Per operative view; (c) Post operative CT scan. 


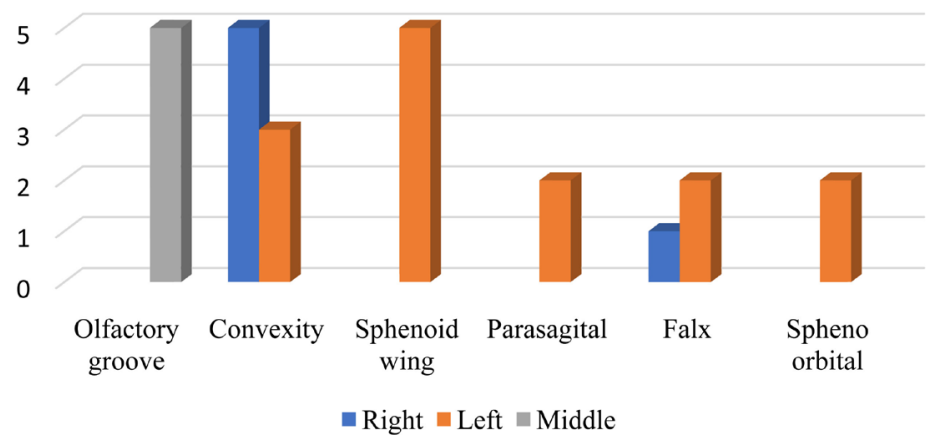

Figure 3. Distribution of meningiomas based on location

\section{Discussion}

Intracranial tumors are common in neurosurgery. Those tumors are associated with high morbidity and mortality. The distribution of these tumors varies across the world. In Africa, patients with intracranial tumors have delayed diagnosis due to late presentation [8]. That could explain the low number of cases in our study. Although, as Ekpene et al. [9], the low histological rate is mostly due to missing data resulting from poor record keeping.

In our study, meningiomas accounted for $47.2 \%$ of intracranial tumors, and had a female preponderance with a statistically significant $(\mathrm{p}=0.025)$ (Table 5). Meningioma is commoner in female as reported in many studies [2] [3] [4] [5] [10] [11]. The high prevalence of meningiomas in our study was reported in studies of Idowu et al. [12] in Ibadan (35\%), Ibebuike et al. [13] in Johannesburg (31.8\%), CBTRUS [14]. However, other reports showed that gliomas were the most common tumor among intracranial neoplasms [15] [16] [17].

Pituitary adenomas had a frequency of $22 \%$ and were seen more in males, according to Jibrin P et al. [18], in Nigeria. In our study, we report a frequency of $18.8 \%$ of pituitary adenomas, more seen in males (60\%). Olasade et al. [18] [19] and Idowu et al. [12] reported a frequency of $17.1 \%$ and $16 \%$ in their studies.

Medulloblastoma and ependymoma were the most common tumors seen in children, in our study. That is similar to Ekpene et al. [9], in Ghana, and Quinn T Ostrom et al. [20], in the United States.

Headache (79.17\%) was the commonest symptom as seen by Ekpene et al. [9] and Howlett [8], followed by visual disturbance (45.88\%), hemiparesis $(58,33 \%)$ and seizure (25\%). For Andrews et al. [21], seizures represented the most common symptom. Preston et al. (10) reported focal neurologic as the commonest symptom.

Supratentorial sites represented $84.9 \%$ of intracranial tumors location. All meningiomas (100\%) were located in the supratentorial region. There was a predominance of convexity meningioma (32\%), followed by olfactory groove (20\%) and sphenoid wing meningiomas (20\%). This is similar to the study of Ekpene et al. [9], and Evangelia et al. [11]. The histological type of meningioma is meningotheliomatous in our study. It is similar to Ekpene's study [9] in Ghana. 
The real incidence rate of intracranial tumors population in Togo, can't be estimated through our study. As Ekpene et al. [9], in Ghana, had observed, based on conjecture, many patients with intracranial tumors don't go to the hospital. They prefer to seek alternative care in prayer camps and with herbal remedy providers. Also, some of those patients with intracranial tumors, are treated in other health facilities within and outside the country.

The surgical site infection in our study is 3.5\%. Helal et al. [22], in Egypt, found a similar rate (3.5\%). This rate reached $8 \%$ in some studies [20] [22] [23] [24].

In our institution, many problems could explain our high rate of mortality (13.2\%):

- The lack of micro neurosurgical equipment, due to their extreme costs, as mentioned by Hellal et al. [22], in Egypt.

- The fact that postoperative care for patients was provided by a basically equipped general ICU with no dedicated neurocritical care nursing staff or equipment [22].

- No intracranial perfusion, or electroencephalography monitoring was available in the ICU.

\section{Conclusion}

Meningioma is the most common intracranial tumor in adults, while embryonal tumors (medulloblastoma and ependymoma) are the most frequent in children in our environment. Healthcare expenditure impacts neurosurgical practice in our country. Some limitations in expenditure affect patients outcomes.

\section{Author Contributions}

Komlan A. Doléagbénou: substantial contributions to conception and design, acquisition of data, drafting the article and revising it critically for important intellectual content; final approval of the version to be published.

Kodjo H.M. Ahanogbé: final approval of the version to be published.

Ablavi O Adani-Ifè: drafting the article and revising it critically for important intellectual content; final approval of the version to be published.

Ben O Djoubairou: drafting the article and revising it critically for important intellectual content; final approval of the version to be published.

Pilakimwé Egbohou: final approval of the version to be published.

Eklu Vossah: final approval of the version to be published.

Komi Egu: final approval of the version to be published.

Essossinam Kpélao: substantial contributions to conception and design, acquisition of data, final approval of the version to be published.

Anthony K Békéti: drafting the article and revising it critically for important intellectual content; final approval of the version to be published.

All authors read and agreed to the final version of this manuscript and equally contributed to its content and to the management. 


\section{Conflicts of Interest}

None.

\section{References}

[1] GLOBOCAN (2002) Worldwide Incidence and Mortality of Cancer, 2002 [Computer Program]. Version. IARC, Lyon.

[2] Mwangombe, N.J. (2000) Brain Tumors at the Kenyatta National Hospital, Nairobi. East African Medical Journal, 77, 444-447.

[3] Soyemi, S.S. and Olugbenga, O.O. (2015) Spectrum of Intracranial Tumors in a Tertiary Health Care Facility: Our Findings. Pan African Medical Journal, 20, 24. https://doi.org/10.11604/pamj.2015.20.24.4935

[4] Elhaj, A., Osman, N., Alobeid, A., Abdallah, A. and Abuidris, D. (2010) Pattern of Brain Tumours among Children in Central Sudan. Sudan J Paediatr and Child Health, 10, 32-34.

[5] Olufunsho, A., Ayokunle, A.A., Deborah, F.A., Vincent, B.F. and Duro, C.D. (2011) Cancer Distribution Pattern in Southwestern Nigeria. Tanzania Journal of Health Research, 13, 1-7. https://doi.org/10.4314/thrb.v13i2.55226

[6] Campbell, B.A., Jhamb, A., Maguire, J.A., et al. (2009) Meningiomas in 2009: Controversies and Future Challenges. American Journal of Clinical Oncology, 32, 73-85. https://doi.org/10.1097/COC.0b013e31816fc920

[7] Wiemels, J., Wrensch, M. and Claus, E.B. (2010) Epidemiology and Etiology of Meningioma. Journal of Neuro-Oncology, 99, 307-314.

https://doi.org/10.1007/s11060-010-0386-3

[8] Howlett, W.P. (2012) Intracranial Tumors. In: Neurology in Africa, University of Bergen, Bergen, 368.

[9] Ekpene, U., Ametefe, M., Akoto, H., Bankah, P., Totimeh, T., Wepeba, G. and Dakurah, T. (2018) Pattern of Intracranial Tumors in a Tertiary Hospital in Ghana. Ghana Medical Journal, 52, 79-83. https://doi.org/10.4314/gmj.v52i2.3

[10] Preston, M.S. (1989) Descriptive Epidemiology of Primary Tumors of the Brain, Cranial Nerves and Cranial Meninges in Los Angeles, Calif, USA. Neuroepidemiology, 8, 283-295. https://doi.org/10.1159/000110196

[11] Liouta, E., Koutsarnakis, C., Liakos, F. and Stranjalis, G. (2015) Effects of Intracranial Meningioma Location, Size, and Surgery on Neurocognitive Functions: A 3-Year Prospective Study. Journal of Neurosurgery, 124, 1-7.

https://doi.org/10.3171/2015.6.JNS1549

[12] Idowu, O.E. and Apemiye, R.A. (2009) Delay in Presentation and Diagnosis of Adult Primary Intracranial Neoplasms in a Tropical Teaching Hospital: A Pilot Study. International Journal of Surgery, 7, 396-398. https://doi.org/10.1016/j.ijsu.2009.07.001

[13] Ibebuike, K., Ouma, J. and Gopal, R. (2013) Meningiomas among Intracranial Neoplasms in Johannesburg, South Africa: Prevalence, Clinical Observations and Review of the Literature. African Health Sciences, 13, 118121. https://doi.org/10.4314/ahs.v13i1.16

[14] Ostrom, Q.T., Cioffi, G., Gittleman, H., Patil, N., Waite, K., Kruchko, C. and Barnholtz-Sloan, J.S. (2019) CBTRUS Statistical Report: Primary Brain and Other Central Nervous System Tumors Diagnosed in the United States in 2012-2016. Neuro-Oncology, 21, v1-v100. https://doi.org/10.1093/neuonc/noz150 
[15] Dobec-Meić, B., Pikija, S., Cvetko, D., et al. (2006) Intracranial Tumors in Adult Population of the Varazdin County (Croatia) 1996-2004: A Population-Based Retrospective Incidence Study. Journal of Neuro-Oncology, 78, 303-310. https://doi.org/10.1007/s11060-005-9100-2

[16] Lona, C., Tabiadon, G., Curro, D.B., et al. (1988) Incidence of Primary Intracranial Tumors in the Province of Bolzano 1980-84. The Italian Journal of Neurological Sciences, 9, 237-241. https://doi.org/10.1007/BF02334046

[17] Campos, S., Davey, P., Hird, A., et al. (2009) Brain Metastasis from an Unknown Primary, or Primary Brain Tumour: A Diagnostic Dilemma. Current Oncology, 16, 62-66. https://doi.org/10.3747/co.v16i1.308

[18] Jibrin, P., Ibebuike, K. and Ado-Wanka, A.N. (2018) Histological Pattern of Intracranial Tumors in the National Hospital, Abuja. African Health Sciences, 18, 281-286. https://doi.org/10.4314/ahs.v18i2.12

[19] Olasode, B.J., Shokunbi, M.T. and Aghadiuno, P.U. (2000) Intracranial Neoplasms in Ibadan, Nigeria. East African Medical Journal, 77, 4-8. https://doi.org/10.4314/eamj.v77i1.46360

[20] Ostrom, Q.T., Gittleman, H., Liao, P., Rouse, C., Chen, Y., Dowling, J., Wolinsky, Y., Kruchko, C. and Barnholtz-Sloan, J. (2014) CBTRUS Statistical Report: Primary Brain and Central Nervous System Tumors Diagnosed in the United States in 2007-2011. Neuro-Oncology, 16, iv1-iv63. https://doi.org/10.1093/neuonc/nou223

[21] Andrews, N.B., Ramesh, R. and Odjidja, T. (2003) A Preliminary Survey of Central Nervous System Tumors in Tema, Ghana. West African Journal of Medicine, 22, 167-172. https://doi.org/10.4314/wajm.v22i2.27942

[22] Helal, A.E., Abouzahra, H., Fayed, A.A., Rayan, T. and Abassy, M. (2018) Socioeconomic Restraints and Brain Tumor Surgery in Low-Income Countries. Journal of Neurosurgery, 45, E11. https://doi.org/10.3171/2018.7.FOCUS18258

[23] Mirski, M.A., Chang, C.W.J. and Cowan, R. (2001) Impact of a Neuroscience Intensive Care Unit on Neurosurgical Patient Outcomes and Cost of Care: Evidence-Based Support for an Intensivist Directed Specialty ICU Model of Care. Journal of Neurosurgical Anesthesiology, 13, 83-92. https://doi.org/10.1097/00008506-200104000-00004

[24] Slattery, W.H., Schwartz, M.S., Fisher, L.M. and Oppenheimer, M. (2004) Acoustic Neuroma Surgical Cost and Outcome by Hospital Volume in California. Otolaryngology_Head and Neck Surgery, 130, 726-735. https://doi.org/10.1016/j.otohns.2004.02.008 